\title{
EFFECT OF FOLIAR SPRAYING WITH MICRONUTRIENTS, ELICITORS, SILICON SALTS AND FERTILIZERS ON POWDERY MILDEW OF SUGAR BEET
}

\author{
E.M. El-Shabrawy and M.S. Abd Rabboh \\ Plant Pathol., Inst., ARC, Giza, Egypt
}

Received: Aug. 24,2020

Accepted: Oct. 17,2020

\begin{abstract}
The capabilities of foliar application by copper sulfate, zinc sulfate, magnesium sulfate and ferrous sulfate as micronutrients, hydrogen peroxides, ascorbic acid and salicylic acid as inducers, potassium silicate and sodium silicate as silicon salts and different combination of NPK, on controlling sugar beet powdery mildew casued by Erysiphe beta were studied. Also, yield and sugar purity and changes in oxidative enzymes, comparable with non-treated plants and Eminent (EW12.5\% I m/L) fungicide were estimated. In greenhouse under artificial infection all treatments significantly decrease disease severity compared with control. Eminent fungicide was the most effective treatment in reducing disease severity, followed by higher concentration of copper sulfate, zinc sulfate, hydrogen peroxide then salicylic acid and potassium silicate. The lowest treatments were NPK combination levels $N_{2} P_{1} K_{1}, N_{1} P_{1} K_{1}, N_{2} P_{2} K_{1}$, ferrous sulfate $10 \mathrm{ppm}$ and sodium silicate at concentration $4 \mathrm{ppm}$. Under field condition, all tested treatments significantly reduced disease severity, while yield and sugar purity were increased in both seasons. Eminent, copper sulfate $20 \mathrm{ppm}$, ascorbic acid $100 \mathrm{ppm}$, zinc sulfate $20 \mathrm{ppm}$ and Hydrogen peroxide followed by salicylic acid $50 \mathrm{ppm}$, potassium silicate $15 \mathrm{~cm}^{3} / \mathrm{L}$ were significantly higher in decreasing disease severity and increasing root weight, sucrose and purity percentage compared with control treatment. Whereas, the lowest treatments in decreasing severity and yield parameters were magnesium sulfate $30 \mathrm{ppm}$ followed by ferrous sulfate then $\mathrm{N}_{1} \mathrm{P}_{2} \mathrm{~K}_{2}$. All tested chemicals significantly increased activity of phenylalanine ammonia lyase (PAL), Polyphenol oxidase (PPO) and Peroxidase (PO) activities in sugar beet leaves compared with control. PAL and PPO activity exhibited the highest value with treatments of hydrogen peroxide $1.5 \%$, ascorbic acid $100 \mathrm{ppm}$, salicylic acid $50 \mathrm{ppm}$, potassium silicate $15 \mathrm{~cm}^{3} / \mathrm{L}$ and copper sulfate 20 ppm followed by zinc sulfate 20 ppm. Meanwhile, PO activity was higher in treatments of hydrogen peroxide $1.5 \%$, potassium silicate $15 \mathrm{Cm}^{3} / \mathrm{L}$, ascorbic acid $100 \mathrm{ppm}$, salicylic acid $50 \mathrm{ppm}$, followed by copper sulfate $20 \mathrm{ppm}$ zinc sulfate $20 \mathrm{ppm}$. On the contrary, $\mathrm{N}_{1} \mathrm{P}_{2} \mathrm{~K}_{2}$ followed by ferrous sulfate $30 \mathrm{ppm}$, magnesium sulfate $30 \mathrm{ppm}$ and eminent were the lowest treatments in enzymes activity compared with control treatment.
\end{abstract}

Key words: Sugar beet, Powdery mildew, micronutrients, elicitors, silicon salts, ferrous.

\section{INTRODUCTION}

Sugar beet (Beta vulgaris L.) is considered as one of the two important sugar cash crops worldwide. In Egypt a total cultivated area reached 8.4 million fedans (Abd El-hady and Bondok 2017). Recently sugar beet surpassed sugar cane in sugar productivity and became the first source of sugar production in
Egypt compared to sugar cane (Hozayn et al., 2013) Powdery mildew of sugar beet is an important disease in several sugar beet growing countries caused by Erysiphe betae (Vanha) Weltzien (Kontaxis et al., 1974; Hills et al., 1980). In Egypt, environmental conditions are favorable for the fungus to spread rapidly especially in the late sowings after 
September (EI-Fahhar, 2008). Disease spread occurs mostly by conidial infections, which dispersed by wind (Kontradowitz and Verreet, 2010). The infection of sugar beet by powdery mildew is economically significant for growers worldwide and can cause sugar yield losses up to $30 \%$ (Francis, 2002). Utilizing disease resistance is an important strategy for controlling plant pathogens because it may be relatively easy to use, cost-effective and environmentally more acceptable than reliance on pesticides (Hogenboom, 1993). Dordas (2008) stated that, in recent years the importance of sustainable agriculture has risen to become one of the most important issues in agriculture. In addition, plant diseases continue to play a major limiting role in agricultural production. The control of plant diseases using classical pesticides raises serious concerns about food safety, environmental quality and pesticide resistance, which have dictated the need for alternative pest management techniques. In particular, nutrients, micronutrients, $\mathrm{Si}$ and inducers could affect the disease tolerance or resistance of plants to pathogens. Also, it has been reported that some phosphate salts induce systemic resistance against various pathogens including powdery mildew of cucumber (Reuveni et al., 1993 and Reuveni et al., 1995).

The objective of this work was to evaluate the efficacy of some micronutrient, chemical inducers and silicon salts and fertilizer treatments to control powdery mildew disease, enhancement of growth parameters on sugar beet yield and oxidative enzymes activity compare with commercial eminent fungicide and control.

\section{MATERIAL AND METHODS}

Greenhouse experiment:
The commercial sugar beet variety Hilospoly was sown in pots $140 \mathrm{~cm}$ diameter) during December and received recommended irrigation and fertilization. Plants were thinned into 3 plants after 30 days of planting. After 12 weeks from cultivation plants were sprayed (Ebrahium, et al., 2016) at 85 days from cultivation with different concentration of

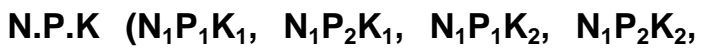
$\mathrm{N}_{2} \mathrm{P}_{1} \mathrm{~K}_{1}, \quad \mathrm{~N}_{2} \mathrm{P}_{2} \mathrm{~K}_{1}, \quad \mathrm{~N}_{2} \mathrm{P}_{1} \mathrm{~K}_{2}$, and $\mathrm{N}_{2} \mathrm{P}_{2} \mathrm{~K}_{2}$ ). Where $\mathrm{N} 1=3 \mathrm{ppm}, \mathrm{N} 2=6 \mathrm{ppm}, \mathrm{P} 1=2 \mathrm{ppm}$, $\mathrm{P2}=5 \mathrm{ppm}, \mathrm{K} 1=4 \mathrm{ppm}, \mathrm{K} 2=6 \mathrm{ppm}$. Whereas, the source of nitrogen $(\mathrm{N})$ fertilizer was Urea $\mathrm{Ch}_{2} \mathrm{~N}_{2} \mathrm{O}$ (N $46 \%$ ), while, Monocalcium phosphate $\mathrm{Ca}\left(\mathrm{H}_{2} \mathrm{PO}_{4}\right) \cdot \mathrm{H}_{2} \mathrm{O}$. ( $P$ 15\%) used as the phosphors source and potassium source was potassium sulfate $\mathrm{K}_{2} \mathrm{SO}_{4} \quad(\mathrm{~K}$ 48\%). Spray with micronutrient, solutions of copper sulfate, ferrous sulfate, magnesium sulfate, zinc sulfate at the concentrations of 10, 20 and $40 \mathrm{ppm}$ were done (Radwan, 2017). Antioxidant compounds, ascorbic acid, salicylic acid at the concentrations of $50 \mathrm{ppm}, 100 \mathrm{ppm}, 200 \mathrm{ppm}$, hydrogen peroxide $\left(\mathrm{H}_{2} \mathrm{O}_{2}\right)$ at the concentration of $0.5 \%, 1 \%, 1.5 \%$ were used. Meanwhile Silicon salts, Potassium silicate $\mathrm{KSiO}_{3}$ content $30 \%$ silicon and $10 \%$ potassium at $5 \mathrm{~cm}^{3} / \mathrm{L}, 10 \mathrm{~cm}^{3} / \mathrm{L}, 15 \mathrm{~cm}^{3} / \mathrm{L}$ and Sodium silicate $\mathrm{Na}_{2} \quad \mathrm{SiO}_{3} \cdot \mathrm{H}_{2} \mathrm{O}$ at concentration of 4 ppm, 8 ppm, 16 ppm. Eminent $12.5 \%$ E.W at rate of $1 \mathrm{~m} / \mathrm{l}$ and control plants sprayed with water as tested treatments.

Inoculation of Erysiphe betae enhancement was accomplished by shaking powdery mildew heavily diseased Sugar beet leaves over the treated plants at a height of about $30 \mathrm{~cm}$. Inoculated plants were kept in greenhouse until disease assessment was undertaken. Inoculation was done 2 days after foliar application with treatments (Strobel and Kuc, 1995).

Field experiment: 
Field experiment was carried out at farmer's field in Sonoras district EIFayoium governorate, during 2018/2019 and 2019/2020 growing seasons. The experiment was designed in the randomized complete blocks method in three replications 4 rows/plot and $80 \mathrm{~cm}$ apart. Sugar beet seeds, c.v. Hilospoly were planted 4 seeds per hill and thinned after 3 weeks to one plant/hill to spacing of $25 \mathrm{~cm}$. All treatments were fertilized by NPK and watering and all cultural practices were affected as recommended by Ministry of Agriculture. The same procedures used in the greenhouse experiment were used in the field trail with an exception that the plants were left for the natural infection and the significant concentration for each treatment reducing the powdery mildew disease as data obtained from greenhouse experiment were used. Where, NPK treatment (N1P2K2), microelements, solutions of copper sulfate $20 \mathrm{ppm}$, ferrous sulfate $30 \mathrm{ppm}$, magnesium sulfate $30 \mathrm{ppm}$, zinc sulfate $30 \mathrm{ppm}$. whereas, inducers ascorbic acid 60 ppm, salicylic acid 50 ppm, hydrogen peroxide $1.5 \%$. Meanwhile, Potassium silicate and Sodium silicate at concentration of $\left(15 \mathrm{~cm}^{3} / \mathrm{L}\right.$ and $8 \mathrm{ppm}$, respectively). The spraying treatments were applied on sugar beet foliage when the first sign of disease was appeared and all treatments were applied three times in 15 day intervals between each spray.

\section{Disease assessment:}

Treatments were evaluates when foliage was closing the rows. Evaluation was accomplished by examining a recently matured leaf on each of at least 50 plants and rating disease intensity as the extent of leaf area covered by fungus mycelium on a scale of 0 to 4 after one week after spraying of treatments. Both sides of a leaf were examined and an average rating was given. Disease severity was determined according the scale by Whitney et al., (1983) Scale ranged from $0-4$, categories whereas $0=$ no mildew colonies observed $1=1-25 \%$, $2=26-50 \%, 3=51-75 \%$ and $4=76-100 \%$ of matured leaf area covered by mildew and the average disease rating per treatment was calculated. Percentage of disease severity was assessed at greenhouse or field experiments after 10 days from each spraying. The percentage of treatment efficiency in the reduction of powdery mildew severity was calculated using this equation. The efficiency of treatments = ((control-treatment)/control) $)^{\star} 100$.

Plant roots were harvested after 5 months from planting and 10 roots were taken randomly for determination of root weight and quality traits for each treatment. Quality traits, Total soluble solids (T.S.S.) \% was measured in fresh roots using the hand refrectometer according to Mc Ginnis (1982), Sucrose $\%$ was determined by using succarometer according to Anonymous (1990) and Purity \% was calculated by using the formula (sucrose \% / T.S.S \%) x (100).

\section{Enzymes assay.}

Effect of application with the compounds related to induce resistance, micronutrients and foliar fertilizing on sugar beet plants defense enzymes were studied from the green house experiment, treated and untreated sugar beet leaves samples were grounded with liquid nitrogen (L-N2) as fine powder with a mortar. One gram of the grounded tissues was mixed with one $\mathrm{ml}$ of extraction buffer phosphate buffer $\mathrm{pH} 6.0$ according to (Bollage et. al., 1996). Samples were vortexes and centrifuged at 13000 r.p.m. for $15 \mathrm{~min}$. under $4^{\circ} \mathrm{C}$ to remove cell debris. The clear supernatant (crude enzyme source) was collected and kept at $-80^{\circ} \mathrm{C}$ for further study (Soltis and Soltis 1990). 


\section{Determination of polyphenol oxidase (PPO).}

Leaf samples were extracted according to the method described by Malik and Singh (1990). The enzyme extract was prepared by grounding $5 \mathrm{~g}$ leaves in $0.1 \mathrm{M}$ sodium phosphate buffer pH 7.0 (2 ml / $\mathrm{g}$ fresh weight), then centrifuged at $6000 \mathrm{rpm}$ for $30 \mathrm{~min}$. under $4{ }^{\circ} \mathrm{C}$. The clear extract was collected, completed to $15 \mathrm{ml}$ volume using phosphate buffer and used as crude enzyme source. The reaction mixture contained $0.2 \mathrm{ml}$ of crude enzyme source, $1 \mathrm{ml}$ of phosphate buffer $\mathrm{pH} 7.0,1 \mathrm{ml}$ of 10-3 $M$ catechol and complete with distilled water up to $6 \mathrm{ml}$. The reaction was incubated for $30 \mathrm{~min}$. at $30{ }^{\circ} \mathrm{C}$. One unite of polyphenol oxidase was expressed as the change in absorbance at $420 \mathrm{~nm} / 30 \mathrm{~min}$. / $1 \mathrm{~g}$ fresh weight (Matta and Dimond, 1963).

\section{Determination of peroxidase (PO):}

The reaction mixture extraction as described by Malik and Singh (1990) was contained $0.5 \mathrm{ml}$ phosphate buffer $\mathrm{pH}$ 7.0, $0.2 \mathrm{ml}$ enzyme source, $0.3 \mathrm{ml}$ of $0.05 \mathrm{M}$ pyrogallol, $0.1 \mathrm{ml}$ of $1 \%(\mathrm{v} / \mathrm{v}) \mathrm{H}_{2} \mathrm{O}_{2}$ and distilled water was added up to obtained $3 \mathrm{ml}$.The reaction mixture was incubated at $30{ }^{\circ} \mathrm{C}$ for $5 \mathrm{~min}$. then the reaction stopped by adding $0.5 \mathrm{ml}$ of $5 \%(\mathrm{v} / \mathrm{v})$ $\mathrm{H}_{2} \mathrm{O}_{2}$ (Kar and Mishra, 1976). One unit of peroxidase activity was expressed as the changes in absorbance at $425 \mathrm{~nm} / \mathrm{min}$. / 1 $\mathrm{g}$ fresh weight.

\section{Phenylalanine ammonia lyase activity:}

Phenylalanine ammonia lyase (PAL) activity, was determined according to the method described by Solecka and Kacperska (2003) with slight modifications by extracting $1 \mathrm{~g}$ of sugar beet leaves in $2 \mathrm{ml}$ of $50 \mathrm{mM}$ borate buffer ( $\mathrm{pH} 8.8$ ) after $24 \mathrm{~h}$ of application using a mortar and pestle at $4^{\circ} \mathrm{C}$, centrifuged at $12000 \mathrm{rpm}$ for $10 \mathrm{~min}$ at $4^{\circ} \mathrm{C}$. The supernatant was used as a source of crude enzyme for assaying PAL activity. Reaction mixture containing $1 \mathrm{ml}$ enzyme extract, $2 \mathrm{ml}$ sodium borate buffer (pH 8.8) and $1 \mathrm{ml}$ of 10-2 M Lphenylalanine was incubated at $30^{\circ} \mathrm{C}$ for $1 \mathrm{~h}$. The enzyme reaction was stopped by adding $500 \mu \mathrm{l}$ of $6 \mathrm{NaHCl}$. The reaction mixture was centrifuged for $10 \mathrm{~min}$ at $12000 \mathrm{rpm}$ to pellet the denatured protein. Enzyme activity was expressed in micromoles of trans-cinnamic acid formed per gram of fresh weight of tissue, measured Unit/hour g/f.w. at 290 $\mathrm{nm}$ by using a spectrophotometer model Unico-2100. Enzyme extract was replaced by distilled water it control blank cuvette.

\section{RESULTS}

\section{Greenhouse experiment:}

Data presented in Table (1) indicated that, all chemical compounds significantly decreased severity of sugar beet powdery mildew under greenhouse conditions compared to the control treatment. The high reduction was achieved by fungicide Eminent $91.9 \%$ followed by the higher concentration of copper sulfate $90.2 \%$ zinc sulfate $89.6 \%$, Hydrogen peroxide $89.2 \%$, salicylic acid and potassium silicate $88.3 \%$. There are no significant differences between those six treatments at higher concentration, followed by five treatments in higher concentration (ascorbic acid, sodium silicate, magnesium sulfate, ferrous sulfate and $\mathrm{N}_{1} \mathrm{P}_{2} \mathrm{~K}_{2}$ ) also showing significant differences with control but not in-between particular chemicals and others where, its disease severity ranged between 9 to $11.7 \%$ without no significant differences in between. Also data revealed that, there are any significant differences between second concentration and third concentration of 
copper sulfate, zinc sulfate and salicylic acid.

Data also show that, tested inducers caused significant reduction in disease severity, the highest treatments was obtained by Hydrogen peroxide at concentration $\quad 1.5 \% \quad(89.2 \% \quad$ Efficacy $)$ followed by salicylic acid 100 ppm (88.3
$\%$ Efficacy) and ascorbic acid 100 ppm (87.9\% Efficacy). Whereas, spraying by silicate salts reduced the disease severity at higher concentrations, spraying with potassium silicate at concentration $15 \mathrm{~cm}^{3} / \mathrm{L}$ achieved $(88.3 \%$ Efficacy) followed by sodium silicate at 8 ppm (87.9\% Efficacy).

Table 1. Effect of micronutrients, inducers, silicon salts and fertilizers on sugar beet powdery mildew, under greenhouse condition, 2018.

\begin{tabular}{|c|c|c|c|}
\hline Treatment & Conc, & Disease severity \% & Efficacy $\%$ \\
\hline \multirow[t]{3}{*}{ Copper sulfate } & 10 ppm & 12.7 & 82.9 \\
\hline & 20 ppm & 9.0 & 87.9 \\
\hline & 30 ppm & 7.3 & 90.2 \\
\hline \multirow[t]{3}{*}{ Zinc sulfate } & 10 ppm & 13.3 & 82.1 \\
\hline & 20 ppm & 10.3 & 86.2 \\
\hline & 30 ppm & 7.7 & 89.6 \\
\hline \multirow[t]{3}{*}{ Magnesium sulfate } & 10 ppm & 16.0 & 78.5 \\
\hline & 20 ppm & 14.3 & 80.8 \\
\hline & 30 ppm & 9.3 & 87.5 \\
\hline \multirow[t]{3}{*}{ Ferrous sulfate } & 10 ppm & 20.0 & 73.2 \\
\hline & 20 ppm & 16.3 & 78.1 \\
\hline & 30 ppm & 10 & 86.6 \\
\hline \multirow{3}{*}{ Ascorbic acid } & 25 ppm & 15.3 & 79.5 \\
\hline & 50 ppm & 12.0 & 83.9 \\
\hline & 100 ppm & 9.0 & 87.9 \\
\hline \multirow[t]{3}{*}{ Salicylic acid1 } & 25 ppm & 18.0 & 75.9 \\
\hline & 50 ppm & 11.3 & 84.8 \\
\hline & 100 ppm & 8.7 & 88.3 \\
\hline \multirow[t]{3}{*}{ Hydrogen peroxide } & $0.5 \%$ & 16.0 & 78.5 \\
\hline & $1 \%$ & 12.0 & 83.9 \\
\hline & $1.5 \%$ & 8.0 & 89.2 \\
\hline \multirow[t]{3}{*}{ Sodium silicate } & 4ppm & 20 & 73.2 \\
\hline & 6ppm & 16.3 & 78.1 \\
\hline & 8ppm & 9 & 87.9 \\
\hline \multirow[t]{3}{*}{ Potassium silicate } & $5 \mathrm{~cm}^{3} / \mathrm{I}$ & 18.3 & 75.5 \\
\hline & $10 \mathrm{~cm}^{3} / \mathrm{I}$ & 13.3 & 82.1 \\
\hline & $15 \mathrm{~cm}^{3} / \mathrm{I}$ & 8.7 & 88.3 \\
\hline \multirow[t]{8}{*}{ N.P.K } & $\mathrm{N}_{1} \mathrm{P}_{1} \mathrm{~K} 1$ & 22.3 & 70.1 \\
\hline & N1P2K1 & 19.0 & 74.5 \\
\hline & N1P1K2 & 14.7 & 80.3 \\
\hline & N1P2K2 & 11.7 & 84.3 \\
\hline & N2P1K1 & 26.7 & 64.2 \\
\hline & N2P2K1 & 20.7 & 72.2 \\
\hline & N2P1K2 & 18.7 & 74.9 \\
\hline & N2P2K2 & 16.0 & 78.5 \\
\hline
\end{tabular}




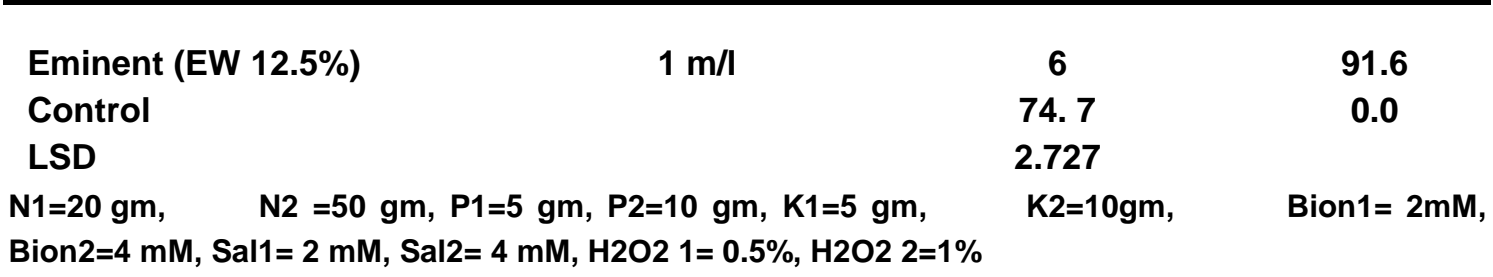

Results in Table (1) show that treatment by NPK combination were lowest in reducing disease severity except $N_{1} P_{2} K_{2}, N_{1} P_{1} K_{2}$ and $N_{2} P_{2} K_{2}$ levels were the most effective NPK combination levels in controlling the disease where, the reduction $(84.4 \%$ and $80.3 \%$, respectively) than the other combinations compared with control. Also data revealed that, the lowest treatments were NPK combination levels $N_{2} P_{1} K_{1}, N_{1} P_{1} K_{1}$, $\mathrm{N}_{2} \mathrm{P}_{2} \mathrm{~K}_{1}$, ferrous sulfate $10 \mathrm{ppm}$ and sodium silicate at concentration $4 \mathrm{ppm}$ where the efficacy achieved were $(64.2 \%$, $70.1 \%, \quad 72.2 \%, \quad 73.2 \%$ and $73.2 \%$, respectively). Generally the reduction in disease severity was significantly increased by increasing concentration of all tested treatments

\section{Field experiment:}

Efficacy of spraying application on sugar beet c.v. Hilospoly naturally infection under field conditions, by selected efficient concentrations previously screened at greenhouse experiment of micronutrients, antioxidants, silicon salts and NPK fertilization, against Erysiphe betae and yield components were carried out in two successful seasons at Sonoras distract farm fields Fayoium governorate, during 2018/2019 and 2019/2020 growing seasons. The selected treatments were second concentration of copper sulfate $20 \mathrm{ppm}$, zinc sulfate $20 \mathrm{ppm}$ and salicylic acid $50 \mathrm{ppm}$ and the higher concentration of the rest of chemicals under study and potassium silicate from silicate salts. Data in Table (2) revealed that, all treatments were significantly decreased disease severity and increasing root weight, sucrose percentage and purity compared with control treatment. The treatments of eminent, copper sulfate 20 ppm, ascorbic acid 100 ppm, zinc sulfate $20 \mathrm{ppm}$ and Hydrogen peroxide followed by salicylic acid $50 \mathrm{ppm}$, potassium silicate $15 \mathrm{~cm}^{3} / \mathrm{L}$ were significantly higher in decreasing disease severity and increasing root weight, sucrose percentage and purity compared with control treatment. Where, treatment by eminent achieved the lower severity $2.9 \%$ obtained $96.5 \%$ reduction and $2.6 \mathrm{~kg}$ root weight followed by copper sulfate $20 \mathrm{ppm}$ where severity was $7 \%, 89.4 \%$ reduction and $2.13 \mathrm{~kg}$ root weight then ascorbic acid 100 ppm $7.1 \%$ severity, $89.1 \%$ reduction and 2 root weight then zinc sulfate $20 \mathrm{ppm}$ where severity was $8.6 \%$ reduction $86.9 \%$, root weight was $1.7 \mathrm{~kg}$, where hydrogen peroxide severity was $9.2 \%, 85.4 \%$ redaction and $1.7 \mathrm{~kg}$ root weight and Salicylic acid $10 \%$ severity and potassium silicate severity was $10.4 \%$ where, reduction was $84 \%$ and $83.4 \%$, respectively. Meanwhile, sucrose purity was higher in copper sulfate 20ppm treatment than other treatments $98.6 \%$ followed by eminent $96.9 \%$, ascorbic acid $100 \mathrm{ppm} 96.3 \%$, zinc sulfate $20 \mathrm{ppm}$ $91.6 \%$ then hydrogen peroxide $87.1 \%$, followed by salicylic acid $85.4 \%$ and potassium silicate $84.1 \%$ purity. Whereas, the lowest treatments in decreasing severity and yield parameters were magnesium sulfate $30 \mathrm{ppm} 13 \%$ severity followed by ferrous sulfate $12.3 \%$ severity then combination of NPK (N1P2K2) $12.7 \%$ severity.

Results in Table (3), indicated that, Eminent 92.6\%, copper sulfate 20 
ppm88.2\%, ascorbic acid 100 ppm 87.3\%, zinc sulfate 20 ppm86.8\%, hydrogen peroxide $84.3 \%$ followed by salicylic acid82.9\% and potassium silicate $81.9 \%$ were superior in controlling disease in second season compared with control treatment. Also the same trend was obtained like first season in disease reduction, yield parameters and sucrose purity $\%$ with slight decreasing in its value and disease reduction percentage.

Table 2. Effect of micronutrients, inducers, silicon salts and fertilizers on sugar beet powdery mildew, under filed condition, 2019.

Treat.

\begin{tabular}{|c|c|c|c|c|c|c|}
\hline Treat. & Inf\% & $\begin{array}{c}\text { Reduc. } \\
\%\end{array}$ & Root W. & T.S.S\% & Suc.\% & Purity\% \\
\hline Copper sulfate 20ppm & $7 f$ & 88.8 & $2.13 \mathrm{~b}$ & $24.6 \mathrm{ab}$ & $24.3 \mathrm{a}$ & 98.6 a \\
\hline Ferrous sulfate 30 ppm & $12.3 \mathrm{bcd}$ & 80.3 & $1.4 \mathrm{de}$ & $20 \mathrm{~cd}$ & $18 \mathrm{~cd}$ & 76.1abcd \\
\hline Magnesium sulfate 30 ppm & $13 b$ & 79.2 & $1.5 \mathrm{de}$ & $20.6 \mathrm{~cd}$ & 17 def & $82.6 \mathrm{de}$ \\
\hline Zinc sulfate 20 ppm & 8.6 ef & 86.2 & $1.7 \mathrm{~cd}$ & $25.3 \mathrm{a}$ & 22 b & 91.6abcde \\
\hline Salicylic acid 50 ppm & $10 \mathrm{de}$ & 84 & $1.61 \mathrm{cde}$ & 26 a & 25 a & $85.4 a b c$ \\
\hline Ascorbic acid 100 ppm & $7.1 \mathrm{f}$ & 88.6 & $2.0 \mathrm{bc}$ & 26.3 a & $20 \mathrm{bc}$ & $96.3 e$ \\
\hline Hydrogen peroxide $1.5 \%$ & 9.2 ef & 85.3 & $1.7 \mathrm{bcd}$ & $18.3 \mathrm{~d}$ & 15.6 ef & 87.1abcde \\
\hline Potassium silicate $15 \mathrm{~cm}^{3} / \mathrm{L}$ & 10.4 cde & 83.4 & $1.6 \mathrm{cde}$ & $19.3 \mathrm{~cd}$ & 16 ef & $84.1 \mathrm{cde}$ \\
\hline N1P2K2 & $12.7 \mathrm{bc}$ & 79.7 & $1.73 \mathrm{bcd}$ & $18.3 \mathrm{~d}$ & $15.3 \mathrm{f}$ & 83.5bcde \\
\hline Eminent (EW 12.5\%) $1 \mathrm{~m} / \mathrm{L}$ & $2.9 \mathrm{~g}$ & 95.3 & $2.6 a$ & 26.3 a & $25.5 \mathrm{a}$ & $96.9 \mathrm{ab}$ \\
\hline Control & $62.7 a$ & - & $1.2 \mathrm{e}$ & 22 bc & 17. $6 \mathrm{de}$ & 80.9 de \\
\hline LSD & 2.55 & & 0.415 & 2.772 & 2.157 & 0.065 \\
\hline
\end{tabular}

Table 3. Effect of micronutrients, inducers, silicon salts and fertilizers, on sugar beet powdery mildew, under filed condition, 2020.

Treat.

Copper sulfate 20ppm

Ferrous sulfate 30 ppm

Magnesium sulfate 30 ppm

Zinc sulfate 20 ppm

Salicylic acid 50 ppm

Ascorbic acid 100 ppm

Hydrogen peroxide $1.5 \%$
Inf\% Reduc.\% Root

$\begin{array}{cccccc}8 \mathrm{f} & 88.2 & 1.93 \mathrm{bc} & 25 \mathrm{ab} & 24 \mathrm{ab} & 96.1 \mathrm{a} \\ 12.3 \mathrm{~cd} & 81.9 & 1.56 \mathrm{~d} & 22.3 \mathrm{bc} & 17.3 \mathrm{ef} & 78.5 \mathrm{~cd} \\ 14.3 \mathrm{c} & 79 & 1.46 \mathrm{de} & 25.3 \mathrm{ab} & 19.6 \mathrm{~d} & 77.9 \mathrm{~d} \\ 9 \mathrm{ef} & 86.8 & 2.2 \mathrm{ab} & 20.6 \mathrm{~cd} & 18 \mathrm{e} & 87.3 \mathrm{abcd} \\ 11.6 \mathrm{~d} & 83 & 1.53 \mathrm{de} & 19 \mathrm{~d} & 15.3 \mathrm{~g} & 80.8 \mathrm{~cd} \\ 8.6 \mathrm{ef} & 87.4 & 1.6 \mathrm{~cd} & 25 \mathrm{ab} & 22.6 \mathrm{bc} & 90.8 \mathrm{abc} \\ 10.6 \mathrm{de} & 84.4 & 1.5 \mathrm{de} & 19.7 \mathrm{~cd} & 15.6 \mathrm{~g} & 81.1 \mathrm{~cd}\end{array}$


E.M. El-Shabrawy and M.S. Abdrabboh

$\begin{array}{lcccccc}\text { Potassium silicate } 15 \mathrm{~cm}^{3} / \mathrm{L} & 12 \mathrm{~cd} & 82.4 & 1.6 \mathrm{~cd} & 25.6 \mathrm{a} & 21.3 \mathrm{c} & 83.1 \mathrm{bcd} \\ \text { N1P2K2 } & 18 \mathrm{~b} & 73.6 & 1.58 \mathrm{~d} & 19.0 \mathrm{~d} & 14.8 \mathrm{~g} & 78.1 \mathrm{~d} \\ \text { Eminent (EW 12.5\%) } 1 \mathrm{~m} / \mathrm{l} & 5 \mathrm{~g} & 92.6 & 2.4 \mathrm{a} & 26.6 \mathrm{a} & 25 \mathrm{a} & 93.7 \mathrm{ab} \\ \text { Control } & 68.3 \mathrm{a} & - & 1.2 \mathrm{e} & 21 \mathrm{~cd} & 16.3 \mathrm{fg} & 77.9 \mathrm{~d} \\ \text { LSD } & 2.645 & & 0.339 & 3.036 & 1.620 & 12.345\end{array}$

Date in Tables $(2,3)$ reveled that disease severity in second season was higher than that in first one which slightly decreased the yield parameters (root weight, sucrose percentage and sucrose purity percentage), also treatments differ in root weight where zinc sulfate comes before copper sulfate and ascorbic acid than first ones. Also copper sulfate was the heist treatment in sucrose purity in both seasons followed by Eminent then ascorbic acid. It was observed that the increasing in disease severity was decreasing yield parameters percentage and purity. Plants treated by eminent, copper sulfate 20 ppm, ascorbic acid 100 ppm, zinc sulfate $20 \mathrm{ppm}$ and hydrogen peroxide $1.5 \%$ were superior in controlling powdery mildew with no significant differences in between in both years.

\section{Biochemical changes in oxidative enzymes activity:}

The effect of selected efficient concentrations of micronutrients, antioxidants, silicon salts and NPK fertilization previously screened at greenhouse experiment as foliar application on various biochemical changes in sugar beet leaves of treated and untreated plants under field natural infection was studied. Data presented in Fig. (1) Indicate that the effect of treatments on phenylalanine ammonia lyase (PAL), Polyphenol oxidase (PPO) and Peroxidase (PO) activities in c.v. Hilospoly sugar beet plants after three times of spraying, all treatments resulted in significant increase in enzymes activity compared to control and fungicide treatments. PAL activity is exhibited the highest value with treatments of hydrogen peroxide $1.5 \%$, ascorbic acid $100 \mathrm{ppm}$, salicylic acid 50 $\mathrm{ppm}$, potassium silicate $15 \mathrm{~cm}^{3} / \mathrm{L}$ and copper sulfate $20 \mathrm{ppm}$ followed by zinc sulfate $20 \mathrm{ppm}(1.3,1.2,1.16,1.1,0.77$ and 0.76 Unit. / hour $g$ /F.W., respectively). The same trend was obtained in PPO activity where, hydrogen peroxide $1.5 \%$, ascorbic acid $100 \mathrm{ppm}$, salicylic acid $50 \mathrm{ppm}$, potassium silicate $15 \mathrm{~cm}^{3} / \mathrm{L}$ and copper sulfate $20 \mathrm{ppm}$ followed by zinc sulfate $20 \mathrm{ppm}(0.70$, $0.68,0.65,0.60,0.47$ and 0.43 Unit./30 min. g/F.W., respectively). 


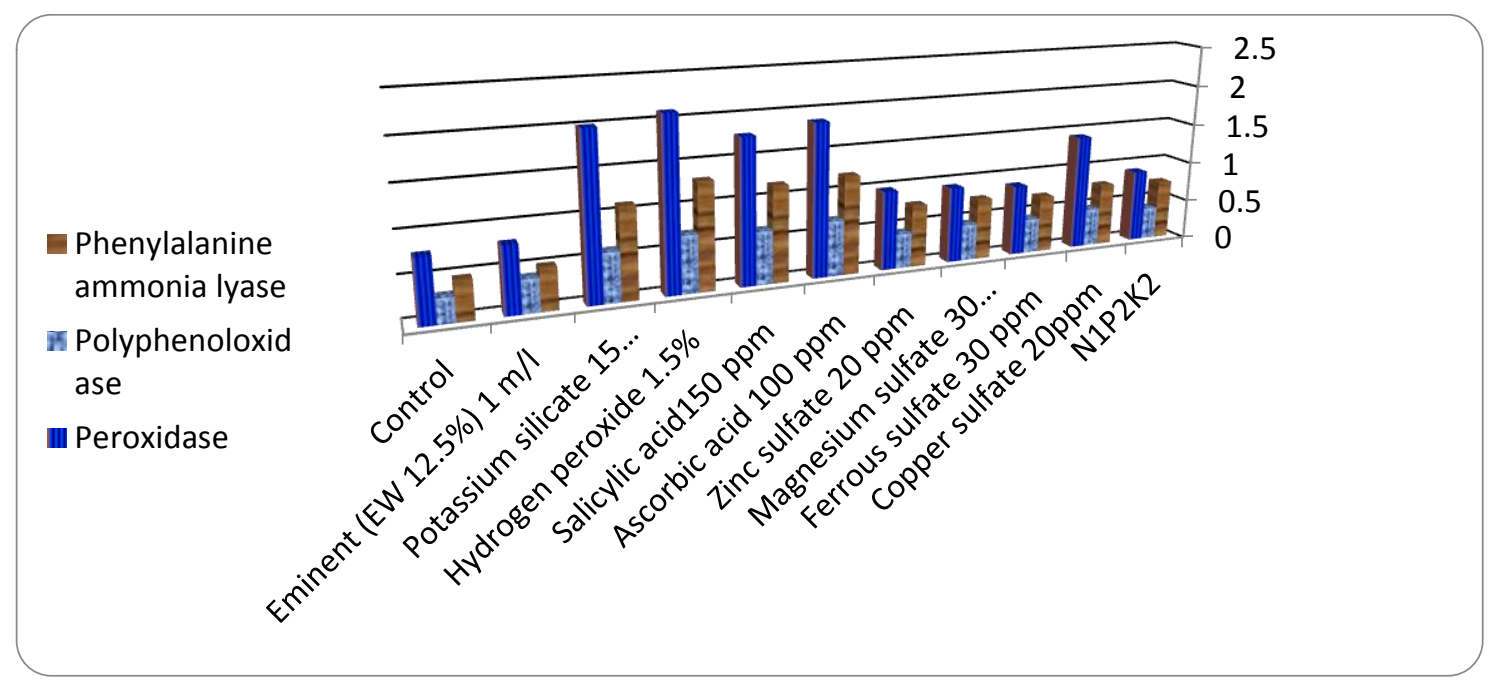

Fig. (1): Effect of foliar treatments of some fertilizers, micronutrients, inducers and silicon salt on enzymes activity of sugar beet.

Concerning to PO activity it was observed that hydrogen peroxide $1.5 \%$, potassium silicate $15 \mathrm{~cm}^{3} / \mathrm{L}$, ascorbic acid $100 \mathrm{ppm}$, salicylic acid $50 \mathrm{ppm}$, are highest treatments in $\mathrm{PO}$ activity at value $(2.1,2, \quad 1.87,1.77$ unit./min. g/F.W., respectively) followed by copper sulfate 20 ppm (1.42) zinc sulfate 20 ppm (0.97) unit./min. g/F.W. On the contrary, $\mathrm{N}_{1} \mathrm{P}_{2} \mathrm{~K}_{2}$ followed by ferrous sulfate $30 \mathrm{ppm}$, magnesium sulfate $30 \mathrm{ppm}$ and eminent were the lowest treatments in enzymes activity compared with control treatment (Fig. 1).

\section{Discussion}

The present study was carried out to investigate the effect of micronutrient, antioxidants, silicon salts and combination levels of NPK fertilization against powdery mildew, plant defense enzymes activity and plant yield component in comparison with Eminent fungicide at recommended concentration and untreated plants (control). In vitro screening of micronutrient, antioxidants, silicon salts and combination levels of NPK fertilization against powdery mildew, in greenhouse under artificial inoculation and selected efficient concentration or chemicals of those treatments from this experiment were applied in the field. The results revealed that, all treatments significantly reduced severity of powdery mildew with slight differences between them comparable with the control. Among the screened thirty five treatments under greenhouse condition results revealed that eleven treatments were significantly superior in reducing powdery mildew. The most efficient treatments were Eminent, copper sulfate zinc sulfate, Hydrogen peroxide, salicylic acid and potassium silicate compared with control treatments followed by ascorbic acid, sodium silicate, magnesium sulfate, ferrous sulfate and N1P2K2 which showing significant differences with control but not inbetween. Meanwhile, treatments in field experiments show progress in ascorbic acid reduction \% than that in greenhouse it comes after Eminent and copper sulfate followed by zinc sulfate, Hydrogen peroxide, salicylic acid and potassium silicate.

Eminent (EW 12.5\%) gave the best protection from powdery mildew, this result is in agreement with (Hemmat and Karima 2017, Abd Elhady and Bondok, 
2017) they reported that Eminent fungicide was superior in controlling sugar beet powdery mildew and enhancement growth parameters. The highest effect of Eminent fungicide could be attributed to its active ingredients mode of action which are belonged to tetraconazol which conceder as sterol dimethylation inhibiting groub (DMI) Lyr (1987) this fungicide group destroying the fungal cell's ability to produce ergosterol causes a disruption of the plasma membrane, thereby resulting in cellular leakage and ultimately the death of the pathogen (Becher and Wirsel, 2012; Karaoglanidis \& Karadimos, 2006).

On the other hand, the fungicides resistant races of pathogen have been reported by (Fernández-Aparicio et al., 2009; Weiland and Koch, 2004). As well as the side effects of fungicides on human health were reported (Durmusoglu et al., 1997; Eckert and Ogawa, 1988) and the environment (Garcia, 1993; Horst et al., 1992). Hence, there is a growing trend many years ago to involve other successful methods in disease management program depending on compounds which are useful, nontoxic and safe either on human health or on the environment especially with the risen of sustainable agriculture importance. In particular, nutrients, micronutrients, Si and inducers could affect the disease tolerance or resistance of plants to pathogens (Dordas, 2008). The results obtained from greenhouse and field experiments were in agreement with this aspect, where the foliar application by micronutrients copper sulfate $30 \mathrm{ppm}$ was the highest treatment from micronutrients it comes after eminent treatment followed by zinc sulfate $30 \mathrm{ppm}$, ferrous sulfate $30 \mathrm{ppm}$ and magnesium sulfate $30 \mathrm{ppm}$ were lowest micronutrient in efficacy than other micronutrients. This result agreed with Eliwa et al., (2018) they reported that using those micronutrients in controlling sugar beet powdery mildew caused significant reduction in disease and increasing micronutrients concentration increasing resistance of sugar beet against powdery mildew disease. Systemic acquired resistance (SAR) may be involved in the suppression of plant diseases by micronutrients. Reduction in disease severity has been reported in other crops after a single foliar application of $\mathrm{H}_{3} \mathrm{BO}_{3}, \mathrm{CuSO}_{4}, \mathrm{MnCl}_{2}$ or $\mathrm{KMnO}_{4}, \mathrm{KH}_{2} \mathrm{PO}, \mathrm{K}_{2} \mathrm{HPO}_{4}$ which provided systemic protection against powdery mildew in cucumber plants (Reuveni et al., 1997a, b; Reuveni and Reuveni, 1998; Reuveni et al., 1998 and Quiroga et al., 2000). The same authors also suggested that application of nutrients such as Mn, $\mathrm{Cu}$ and $\mathrm{B}$ can exchange and therefore release $\mathrm{Ca} 2+$ cations from cell walls, which interact with salicylic acid and activate systemic acquired resistance mechanisms. Micronutrients play an important role in plant metabolism by affecting the phenolics and lignin content and also membrane stability (Graham and Webb, 1991). Micronutrients can affect resistance indirectly, as in deficient plants they become more suitable feeding substrate.

Concerning the tested inducers the highest treatment was obtained by hydrogen peroxide at concentration $1.5 \%$ followed by ascorbic acid $100 \mathrm{ppm}$ then salicylic acid $100 \mathrm{ppm}$ in greenhouse experiment. In field experiment ascorbic acid $100 \mathrm{ppm}$ was superior in reducing severity followed by hydrogen peroxide $1.5 \%$ and salicylic acid $50 \mathrm{ppm}$. Data are in agreement with those reported by several researchers when they used inducers against several plant diseases caused by various pathogens (Sklodowska et al., 2010; Vimala and Suriachandraselvan, 2009; El-Samawaty \& Galal, 2009; Ismail et al., 2006; Shaat \& Galal, 2004; Sparla et al., 2004; Galal \& Abdou, 1996). The reason for that effectiveness could be explained that 
many factors may act on plants to induce high levels of systemic resistance to subsequent pathogen attack. Induction of resistance due to spraying of SA, $\mathrm{KH}_{2} \mathrm{PO} 4, \mathrm{~K}_{2} \mathrm{HPO}_{4}, \mathrm{H}_{2} \mathrm{O}_{2}$ and $\mathrm{BTH}$ may be attributed to different factors affecting host-pathogen reaction. Among these factors pathogenesis related proteins, peroxidase, $\beta$-1,4-gluconase and chitinase which are actively accumulated in immunized plants (Quiroga et al., 2000). The role of hydrogen peroxide in activation of an array of host defense mechanisms including induced activity of enzymes as peroxidase and chitinase accompanied by a significant increase in the lignin and suberin content (Gusui et al., 1997). Hydrogen peroxide positively influences the local and systemic accumulation of SA that is correlated with the enhancement of peroxidase activity (Martinez et al., 2000). Moreover, hydrogen peroxide inhibits pathogens directly, and /or it may generate other reactive free radicals that are antimicrobial (Peng and Kuc, 1992). On the other hand, Eliwa et al. (2018) they stated that the foliar application of inducers significantly reduced severity of disease and the lowest area under powdery mildew progress curve (AUPMOC) value was obtained by Billis fungicide followed by salicylic acid and ascorbic acid.

Regarding to silicon salts treatments whether in the greenhouse or the field results indicate that, a significantly reduction was achieved in the disease infection comparable to the control. Efficiency in decreasing the disease incidence was increased by increasing the compound concentrations potassium silicate was higher than sodium silicate in reducing severity. Results throughout this study led to the hypothesis that Si would act as a modulator influencing the plant defense response as suggested by Fawe et al. (2001). They emphasized that $\mathrm{Si}$ act as a secondary messenger of systemic acquired resistance (SAR). It is believed that $\mathrm{Si}$ creates a physical barrier which can restrict fungal hyphae penetration, or it may induce accumulation of antifungal compounds such as flavonoid and diterpenoid phytoalexins which can degrade fungal and bacterial cell walls (Alvarez and Datnoff, 2001; Brescht et al., 2004).

Treatments with N.P.K. combinations revealed that, the balance between the three fertilize elements was significantly deference in reducing disease severity compared with control, spraying with low nitrogen level high $K$ and $P$ combination (N1P2K2) was the most efficient ones than other combinations this result are in agreement with several investigation studied the effect of NPK on several diseases they reported that obligate parasites severity increased by increasing $\mathbf{N}$ supply (Dordas, 2008; Büschbell and Hoffmann, 1992), the foliar application of $\mathrm{K}$ may promote the development of thicker outer walls in epidermal cells, Tissue hardening, influence plant metabolism Marschner (1995). Also, a number of other studies have shown that foliar application of $P$ can induce local and systemic protection against powdery mildew in cucumber, roses, wine grapes, mango and nectarines (Reuveni and Reuveni, 1998; Huber and Graham, 1999; Reuveni et al., 2000).

Regarding to growth parameters data in this study revealed that, all treatments were significantly increasing root weight, sucrose percentage and purity compared with control treatment. The treatments of Eminent, copper sulfate 20 ppm, ascorbic acid $100 \mathrm{ppm}$, zinc sulfate $20 \mathrm{ppm}$ and Hydrogen peroxide followed by salicylic acid $50 \mathrm{ppm}$, potassium silicate $15 \mathrm{~cm}^{3} / \mathrm{L}$ were significantly higher in increasing root weight, sucrose percentage and purity compared with control treatment. These results were in agreement with the 
findings of Rossi, et al. (2000) they described the effect of disease on yield component as a result of reduction of photosynthetic activity of leaf area firstly. Under severe foliage loss, late season photosynthetic potential is also reduced and vegetative re-growth is stimulated at the expense of root sugar reserves. As a consequence, potential sugar yield (recoverable sugar) of sugar beet crop can be significantly reduced due to the loss of both root weight and sucrose content. Therefore, any suppression of disease development will lead to save yield reduction or increasing yield components than that of untreated plots. Percich et al. (1987), Khan and Smith (2005) and Gado (2007), they reported that treated plots of sugar beet by fungicides resulted in increase in yield components, root weight and sucrose $\%$, due to suppressing the causal agent of Cercospora leaf spot disease. Concerning the effect of the previously mentioned chemicals on yield components, obtained results showed that, hydrogen peroxide, salicylic acid micronutrients have significantly increased root weight / plant, sucrose and juice quality percentage. Similar results were reported by (Salama, 2006; Zaky et al., 2006 and Gehan et al., 2013). Results revealed that Potassium silicate significantly reduced the disease severity also increased growth parameters and sugar yield and purity this results are in agreement with the findings of Abd Elhady and Bondok (2017) they investigated that foliar application of potassium silicate compared with non treated sugar beet plants and Eminent fungicide was significantly reduced powdery mildew and enhanced growth and productivity and sugar yield. The lowest treatments in decreasing yield parameters and sucrose purity $\%$ were ferrous sulfate followed by magnesium sulfate N1P2K2 treatment.

Concerning to oxidative enzymes activity the obtained results indicated that PAL and PPO activity is exhibited the highest value with treatments of hydrogen peroxide $1.5 \%$, ascorbic acid $100 \mathrm{ppm}$, salicylic acid $50 \mathrm{ppm}$, potassium silicate $15 \mathrm{~cm}^{3} / \mathrm{L}$ and copper sulfate $20 \mathrm{ppm}$ followed by zinc sulfate 20 ppm. Meanwhile, N1P2K2 followed by ferrous sulfate $30 \mathrm{ppm}$, magnesium sulfate $30 \mathrm{ppm}$ and Eminent were the lowest treatments in enzymes activity compared with control treatment. It was observed that inducers achieved higher levels of enzymes activity than micronutrients, results gave evidence that spraying sugar beet plants with previously mentioned chemicals increase activity of oxidative enzymes in plant leaves compared with control treatment which increased reduction to powdery mildew and increased growth parameters and sugar yield and purity percentage. This is in agreement with those reported by Reuveni et al. (1997); Abd-El-Kareem (1998) and El-Habbak, (2003). Many plant enzymes are involved in defense reaction against plant pathogen. These included oxidative enzymes such as peroxidase and polyphenoloxidase which catalyses the formation of lignin and other oxidative phenols that contribute to formation of defense barriers for reinforcing the cell structure (Avdiushko et al., 1993; Gusui et al.1997; and Mahmoud et al., 2006). Enzyme activity played an important role in plant disease resistance through increasing plant defense mechanisms that are considered the main tool of varietal resistance (Takuo et al., 1993). Hydrogen peroxide positively influences the local and systemic accumulation of salicylic acid that is correlated with the enhancement of peroxidase activity (Martinez et al., 
2000). Moreover, hydrogen peroxide inhibits pathogens directly, and/or it may generate other reactive free radicals that are antimicrobial (Peng and Kuc, 1992). Also results indicated that spraying sugar beet plants with SA increased activity of oxidative enzymes in plant leaves than untreated infected control. This is in agreement with (Zaky et al., 2006; Thabet, 2008; and Hammat et al., 2016) they stated that there was a significant increase in the activity of PO and PPO after spraying wheat, anise and sugar beet plants with salicylic acid. This might be due to the role of salicylic acid in generation of the oxidative burst in incompatible interactions by inducing a rapid transient generation of $\mathrm{O}_{2}^{-}$which is responsible for regulation of peroxidase activity (Rao et al., 1997).

Phenylalanine ammonia lyase (PAL) is the primary entry enzyme that leads to phenylpropanoid pathway resulting in the biosynthesis of a diverse array of plant metabolites, such a cinnamic, coumaric, ferulic and caffeic acids, flavonoids, tannins and lignin (Hahlborck and Sheel, 1989). These products consequently protect plants against various abiotic stresses and pathogenic attacks (Jones, 1984). Plants may accumulate phenolics through the phenylpropanoid pathway on activation of PAL as a means of passive defence (Barry and Manley, 1986) and the magnitude of the accumulation primarily depends on the supply of the primary precursor, L-phenylalanine (Da Cunha, 1987).

\footnotetext{
The increase of PO and PPO activity was associated with increasing resistance against infection by many diseases (Wang et al., 2000). The role of peroxidase, and other enzymes were also investigated as markers for resistance (Hammerschmidt et al., 1982). peroxidases also may be responsible for
}

the production of $\mathrm{H}_{2} \mathrm{O}_{2}$ (Bolwell et al., 2002). $\mathrm{H}_{2} \mathrm{O}_{2}$ produced by these peroxidases might serve as the substrate for other peroxidases, or act as an antimicrobial agent and signals to trigger self-defence responses like hypersensitive reaction (Wojtaszek, 1997). Peroxidases have roles in both the production and scavenging of reactive oxygen species (Bolwell et al., 2002). Polyphenoloxidases (PPO) generally catalyse the oxidation of phenolic compounds to quinones (antimicrobial compounds) using molecular oxygen as an electron acceptor (Sommer et al., 1994) which are toxic to the invading pathogens and pests (Weir et al., 2004).

\section{REFERENCES}

Abd Elhady, M.A. and A.M. Bondok (2017). Impact of potassium silicate on growth, productivity and powdery mildew disease of sugar beet under newly reclaimed soil conditions. Middle East Journal of Agriculture, Vol: 6, Issue: 4, pages: 1232-1242.

Abd-El-Kareem, F.M.A. (1998). Induction of resistance to some diseases of cucumber plants grown under greenhouse conditions. Ph.D. Thesis, Agric., Ain Shams Univ.

Alvarez, J., L.E. Datnoff (2001). The economic potential of silicon for integrated management and sustainable rice production, Crop Prot. 20, 43-48.

Anonymous. (1990). Association of Official Analytical Chemists. Official methods analysis of the association of official analytical chemists. Washington 25.D., USA.

Avdiushko, S.A., X.S. Ye and J. Kuc (1993). Detection of several enzmetic activities in leaf prints of cucumber plants. Physiological and Molecular Plant Pathology, 42: 441-454. 
Barry, T.N. and T.R. Manley (1986). Interrelationships between concentrations of total condensed tannins, free condensed tannin and lignin in Lotus sp. and their possible consequences in ruminant nutrition. $J$. Sci. Food Agric., 37: 248-254.

Becher, R., S.G. Wirsel (2012). "Fungal cytochrome P450 sterol 14ademethylase (CYP51) and azole resistance in plant and human pathogens". Applied Microbiology and Biotechnology. 95 (4): 825-40.

Bollage, M.D., D. M. Rozycki and J. S. Edelstein (1996). Protein Methods. Wiley-Liss; Inc.; New York. 413pp.

Bolwell, G.P., L.V. Bindschedler, K.A. Blee, V.S. Butt, D.R. Davies, S.L. Gardner, C. Gerrish and F. Minibayeva (2002). The apoplastic oxidative burst in response to biotic stress in plants: a three-component system. J. Exp. Bot., 53: 1367-1376.

Brescht, M.O., L.E. Datnoff, T.A. Kucharek and R.T. Nagata (2004). Influence of silicon and chlorothalonil on the suppression of grey leaf spot and increase plant growth in St. Augustinegrass, Plant Dis. 88, 338344.

Büschbell, T. and G.M. Hoffmann (1992). The effects of different nitrogen regimes on the epidemiologic development of pathogens on winter wheat and their control, J. Plant Dis. Prot. 99, 381-403.

Da Cunha, A. (1987). The estimation of phenylalanine ammonia lyase shows phenylpropanoid biosynthesis to be regulated by L-phenylalanine supply and availability. Phytochemistry 26: 2723-2727.

Dordas, C. (2008). The role of nutrients in controlling plant diseases in sustainable agriculture. A review. Agronomy for Sustainable Development 28 (1) 33-46.

Durmusoglu, E., W. Massfeld and C. Sengonca (1997). Determination of the exposure of workers to two different pesticides in a greenhouse with roses. Mitteilungen der Deutschen Gesellschaft fur Allgemeine und Angewandte Entomologie. 11(1/6): 319-322.

Ebrahium Hemmat, A. and Karima G. Helmy (2016). Impact of some treatments on sugar beet powdery mildew. Assiut J. Agric. Sci., (47) No. (6-1): 100-119.

Eckert, J.W. and J.M. Ogawa (1988). The chemical control of postharvest diseases, deciduous fruits, berries, vegetable and root/tuber crops. Annual Review of Phytopathology 26: 433-469.

El-Fahhar, Samia A. (2008). Impact of powdery mildew disease on root weight, sugar yield and purity of sugar beet. Journal Agricultural ResaerchKafr EISheikh University. 34(1): 309320.

El-Habbak, M. H. (2003). Induction of resistance to powdery mildew disease of Squash plants. M.Sc. thesis, Fac. of Agric., Mosh. Zagazig Univ., Benha Branch.

Eliwa, M.A., M.M. El-Sheikh Aly, H.M. Abd-Alla and A.A. Galal (2018). Efficacy of certain fungicide alternatives for controlling sugar beet powdery mildew. Journal of phytopathology and Pest Management.5 (1):76-87.

El-Samawaty, A.M.A. and A.A. Galal (2009). Use of benthiodiazole (BTH) for inducing systemic resistance in cotton seedlings against some soilborne pathogenic fungi. Journal of Agricultural Science - Mansoura University 34(4): 3305-3315. 
Fawe, A., J.G. Menzies, M. Cherif and R.R. Belenger (2001). Silicon and disease resistance in dicotyledons. In: Silicon in Agriculture (Dantoff, L.E., Snyder, G.H. and Krondofer G.H., Eds.), pp. 159-170.

Fernández-Aparicio, M., E. Prats, A.A. Emeran and D. Rubiales (2009). Characterization of resistance mechanisms to powdery mildew (Erysiphebetae) in beet (Beta vulgaris). Phytopathology 99: 385389.

Francis, S.A. (2002). Sugar-beet powdery mildew (Erysiphebetae). Molecular Plant Pathology 3:119-124.

Gado, E. A. M. (2007). Management of cercospora leaf spot disease of sugar beet plants by some fungicides and plant extracts. Egypt. J. Phytopathol., 35(2):1-10.

Galal, A.A. and E.I.S. Abdou (1996). Antioxidants for the control of fusarial disease in cowpea. Egyptian Journal of Phytopathology 24: 1-12.

Garcia, J.E. (1993). Pesticides as contaminants. Turrialba (Costa Rica), 43(3): 221-229.

Gehan, A. Amin, Elham A. Badr and M.H.M. Afifi (2013). Root yield and quality of sugar beet (Beta vulgaris L.) in response to biofertilizer and foliar application with micronutrients. World Applied Sciences journal. 27(11):13851389.

Graham, D.R. and M.J. Webb (1991). Micronutrients and disease resistance and tolerance in plants, in: Mortvedt J.J., Cox F.R., Shuman L.M., Welch R.M. (Eds.), Micronutrients in Agriculture, 2nd ed., Soil Science Society of America, Inc. Madison, Wisconsin, USA, pp. 329-370.

Gusui, W.U., B.J. Shortt, E.B. Lawrence, J. Leon, K.C. Fitzsimmons, E.B.
Levine, I. Raskin, D.M. Shah and G.S. $\mathrm{Wu}$ (1997). Activation of host defense mechanisms by elevated production of $\mathrm{H}_{2} \mathrm{O}_{2}$ in transgenic plants. Plant Physiol., 115: 427-435.

Hahlborck, K. and D. Sheel (1989). Physiology and molecular biology of phenylpropanoid metabolism. Plant Mol. Biol., 40: 347- 369.

Hammerschmidt, R., E.M. Nuchles and J. Kuc (1982). Association of enhanced peroxidase activity which induce systemic resistance of cucumber to Colletotrichum lagenarium. Physiol. Plant Pathol., 20: 73-82.

Hills, F.J., L. Chiarappa and S. Geng (1980). Powdery mildew of sugar beet: Disease and crop loss assessment. Phytopathology, 70: 680-682.

Hogenboom, N.G. (1993). Economic importance of breeding for disease resistance, Indurability of disease resistance, Kluwer Dordrecht, 5-9 pp.

Horst, R.K., S.O. Kawamoto and L.L. Porter (1992). Effect of sodium bicarbonate and oils on control of powdery mildew and black spot of roses. Plant Disease 76: 247-251.

Hozayn, M., M.M. Tawfik, H.M. Abd ElGhany and A.M. Korayem (2013). Effect of plant density on yield and sugar qulity characteristics of sugar beet. J. Appl. Sci. Research, 9(1): 1004-1009.

Huber, D.M. and R.D. Graham (1999). The role of nutrition in crop resistance and tolerance to disease, in: Rengel $Z$. (Ed.),Mineral nutrition of crops fundamental mechanisms and implications, Food Product Press, New York, pp. 205-226.

Ismail, M.E., H.M. Abdalla and A.A. Galal (2006). Factors affecting induced resistance in sunflower plants against basal stem rot caused by Sclerotium 
rolfsii (Corticumrolfsii). Minia Journal of Agricultural Research and Development 26(3): 405-425.

Jones, D.H. (1984). Phenylalanine ammonia lyase regulation of its induction and its role in plant development. Phytochemistry, 23: 1349-1359.

Kar, M. and D. Mishra (1976). Catalase; peroxidase and polyphenoloxidase activities during rice leaf senescence. Plant Physiology 57:315-319.

Karaoglanidis, G.S. and D.A. Karadimos (2006). Efficacy of strobilurinsand mixtures with DMI fungicides in controlling powdery mildew infieldgrown sugar beet. Crop Protection 25: 977-983.

Khan, M. F. R. and L. J. Smith (2005). Evaluating fungicides for controlling Cercospora leaf spot on sugar beet. Crop Protection, 24: 79-86.

Kontaxis, D.G., H. Meister and R.K. Sharma (1974). Powdery mildew epiphytotic on sugar beets. Plant Dis. Rep., 58: 904-905.

Kontradowitz, L. and J.A. Verreet (2010). Assessment of resistance and virulence in the pathosystem sugar beet (Beta vulgaris)/powdery mildew (Erysiphebetae) - development of basics for an effective powdery mildew resistance breeding Journal of Plant Diseases and Protection 117 (2): 49-54.

Lyr, H. (1987). Modern selective fungicides: properties, applications, mechanisms of action. Longman Scientific and Technical, Essex, England.387 pp.

Mahmoud, E.Y., S.Y.M. Shokry and Z.N. Hussin (2006). Induction of resistance in peanut plants against root rot diseases under greenhouse conditions by some chemical inducers. J. Agric. Sci., Mansoura Univ., 31 (6): 3511-3524.

Malik, C. P. and M. B. Singh (1990). Extraction and estimation of amino acids and kito acids.In:Plant Enzymology and histoEnzymology.New Delhi-Lud Hana; India.

Marschner, H. (1995). Mineral Nutrition of Higher Plants, 2nd ed., Academic Press, London, p. 889.

Martinez, C., J.C. Baccou, E. Bresson, Y. Baissac, J. Franc, O. Daniel, A. Jalloul, J.L. Montillet, J.P. Geiger, K. Assigbetse and M. Nicole (2000). Salicylic acid mediated by the oxidative burst is a key molecule in local and systemic responses of cotton challenged by an avirulent race of Xanthomonas campestris pv. malvacearum. Plant Physiol., 122: 757766.

Matta, A. and A.E. Dimond (1963). Symptoms of Fusarium Wilt in relation to quantity of fungus and enzyme activity in tomato stems. Phytopathology; 53:574-587.

Mc Ginnis, R.A. (1982). Beet Sugar Technology $3^{\text {rd }}$ ED. Beet Sugar Development for Collins. 855pp.

Peng, M. and J. Kuc (1992). Peroxidasegenerated hydrogen peroxide as a source of antifungal activity in vitro and on tobacco leaf disks. Phytopathology, 82: 696-699.

Percich, J.A., L.J. Nickelson and C.M. Hout (1987). Field evaluation of various fungicides to control Cercospora leaf spot of sugar beet, caused by Benomyl-resistant strains of Cercospora beticola. Journal of A.S.S.B.T. 24: 32-40.

Quiroga, M., C. Guerrero, M.A. Botella, Amaya I. Barcelo, M.I. Medina, F.J. Alonso, de. A.M. Forchetti, H. Tigier 
and V.A. Valpuesta (2000). Tomato peroxidase involved in the synthesis of lignin and suberin. Plant Physiol., 122: 1119-1127.

Radwan, K.S.A. (2017). Integrated management of tomato wilt and root rot diseases, PhD thesis, Faculty of Agriculture, Minia University, Minia, Egypt, 140 pp.

Rao, M.V., G. Paliath, D.P. Ormod, D.P. Murr and C.B. Watkins (1997). Influence of salicylic acid on $\mathrm{H} 2 \mathrm{O} 2$ production, oxidative stress and H2O2-metabolizing enzymes. Plant Physiol., 115: 137-149.

Reuveni, M., V. Agapov and R. Reuveni (1997a). A foliar spray of micronutrient solutions induces local and systemic protection against powdery mildew (Sphaerotheca fuliginea) in cucumber plants, Eur. J. Plant Pathol. 103, 581588.

Reuveni, M., D. Oppernheim and R. Reuveni (1998). Integrated control of powdery mildew on apple trees by foliar sprays of mono-potassium phosphate fertilizer and sterol inhibiting fungicides, Crop Prot. 17, 563-568.

Reuveni, R., G. Dor, M. Raviv, M. Reuveni and S. Tuzun (2000). Systemic resistance against Sphaerotheca fuliginea in cucumber plants exposed to phosphate in hydroponics system, and its control by foliar spray of mono-potassium phosphate, Crop Prot. 19, 355-361.

Reuveni, R. and M. Reuveni (1998). FoliarFertilizer therapy - a concept in integrated pest management, Crop Prot. 17, 111-118.

Reuveni, M., V. Agapov and R. Reuveni (1995). Induced systemic protection to powdery mildew in cucumber by phosphate and potassium fertilizers: Effects of inoculums concentration and post inoculation treatment. Canadian Journal of Plant Pathology, 17: 247-251.

Reuveni, M., V. Agapov and R. Reuveni (1997). A foliar spray of micronutrient solutions induces local and systemic protection against powdery mildew (Sphaerotheca fuliginea) in cucumber plants. European Journal of Plant Pathology, 103(7): 581-588.

Reuveni, M., V. Agapov and R. Reuveni (1997b). Controlling powdery mildew caused by Sphaerotheca fuliginea in cucumber by foliar sprays of phosphate and potassium salts, Crop Prot. 15, 49-53.

Reuveni, M., V. Agapov and R. Reuveni (1993). Induction of systemic resistance to powdery mildew and growth increase in cucumber by phosphates. Biological Agriculture and Horticulture, 9: 305-315. (Abstract).

Rossi, V., P. Meriggi, E. Biancardi and F. Rosso (2000). Effect of Cercospora leaf spot on sugar beet growth, yield and quality. In Advances in Sugar beet Research Vol. 2: Cercospora beticola Sacc. Biology, agronomic influence and control measures in sugar beet, ed. M.J.C. Asher, B. Holtschulte, M. Richard Molard, F. Roso, G. Steinruecken, and R. Beckers, 49-76. Brussels: International Institute for Beet Research.

Salama, N.H.H. (2006). Integrated control of sugar beet diseases in Egypt. Ph.D. Thesis, Plant Pathol. Dept., Fac. Agric., Mansoura Univ., Egypt, 167 pp.

Shaat, M.N.M. and A.A. Galal (2004). Response of citrus fruits to preharvest to antioxidants spraying and infection with Alternaria fruit rot and green mold. Annals of Agricultural Sciences 49: 747-758. 
Sklodowska, M., E. Gajewska, E. Kuzniak, A. Mikicinski and P. Sobiczewski (2010). BTH-mediated antioxidant system responses in apple leaf tissues. Scientia Horticulture 125: 34 40.

Solecka, D. and A. Kacperska (2003). Phenylpropanoid deficiency affects the course of plant acclimation to cold. Physiol. Plantarum, 119: 253 262.

Soltis, D. E. and P. S. Soltis (1990). Isozymes in Plant Biology. Dioscorides press; Portland; Oregon pp.259.

Sommer, A., E. Neeman, J.C. Steffens, A.M. Mayer and E. Harel (1994). Import, targeting and processing of a plant polyphenoloxidase. Plant Physiol., 105: 1301-1311.

Sparla, F., L. Rotino, M.C. Valgimigli, P. Pupillo and P. Trost (2004). Systemic resistance induced by benzothiadiazole in pear inoculated with the agent of fire blight (Erwinia amylovora). Scientia Horticulture 101(3): 269-279.

Strobel, N. E. and J. A. Kuc (1995). Chemical and biological inducers for systemic resistance to pathogens protect cucumber and tobacco plants from damage caused by paraquat and cupric chloride. Phytopathology, 85: 1306-1310.

Takuo, S., S. Tatsuji, H. Johan and V. Erick (1993). Pectin, Pectinase and Protopectinase: protection, properties and applications. Adv. Appl. Microbiol., 39: 213-294.

Thabet, M.S. (2008). Induction of resistance in wheat plants against leaf rust disease caused by Puccinia triticina. M.Sc. Thesis, Plant Pathol. Dept., Fac. of Agric., Ain Shams Univ. Egypt, 122 pp.

Vimala, R. and M. Suriachandraselvan (2009). Induced resistance in bhendi against powdery mildew by foliar application of Salicylic acid, Journal of Biopesticides 2(1): 111-114.

Wang, F., R.J. Gao, J.O. Li, X.H. Wu and P.T. Geny (2000). Effect of difenoconazole on the growth and activities of disease resistance related enzymes in wheat seedlings from treated seeds. Acta Phytopathologica Sinica,30: 213-216.

Weiland, J.J. and G. Koch (2004). Sugarbeet leaf spot disease (Cercospora beticola Sacc.). Molecular Plant Pathology. 5: 157-166.

Weir, T.L., S.W. Park and J.M. Vivanco (2004). Biochemical and physiological mechanisms mediated by allelochemicals. Curr. Opin. Plant Biol., 7: 472-479.

Whitney, E.D., R.T. Lewellen and I.O. Skoyen (1983). Reaction of sugar beet to powdery mildew: Genetic variation, association among testing procedures, and results of resistance breeding. Phytopathology, 73: 182185.

Wojtaszek. P. (1997). Oxidative burst: an early plant response pathogen infection. Biochem., J., 322: 681-692.

Zaky, W.H., M.G.A. Nada and A.A. Hilal (2006). Evaluation of the efficiency of some environmentally safe means for controlling rust disease of anise (Pimpinella anisum L.), as important medicinal plant in Egypt. Egypt. J. Phytopathol., 34 (2): 103 - 119. 
تاثير الرش الورقى بالمغذيات الصغرى والمستحثات واملاح السيليكون والاسمده على البياض الدقيقى فى بنجر السكر

السعيد محمد الشبراوى، مدحت سعيا عبدريها

معهد بحوث امراض النباتات - مركز البحوث الزراعية

الملخص العربى

تم دراسة كفاءة العناصر الصغرى وهى كبريتات النحاس وكبريتات الزتك وكبريتات الماغنسيوم وكبريتات الحديد،

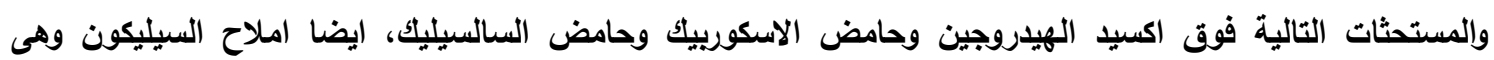

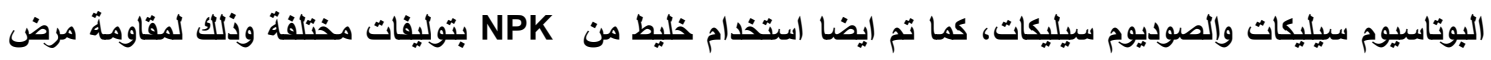
البياض الدقيقى فى بنجر السكر المتسبب عن فطر الإيريسيف بيتا. كما تم ايضا دراسة التأثير على وزن المحصول

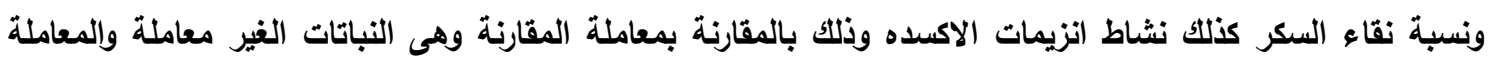

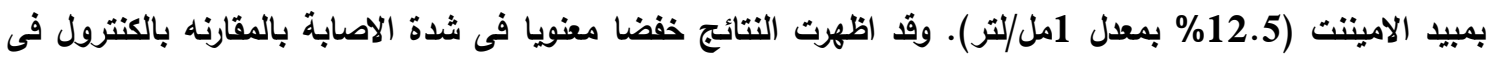
الصوية تحت ظروف العدوى الصناعية. وكاتت المعامله بمبيد الايمينت افضل المعاملات تاثيرا فى خفض شدة الاصابه

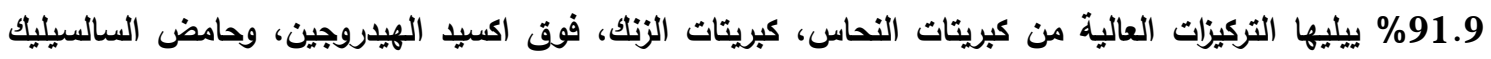
وسيليكات البوتاسيوم. بينما كانت اقل المعاملات تاثيرا خليط

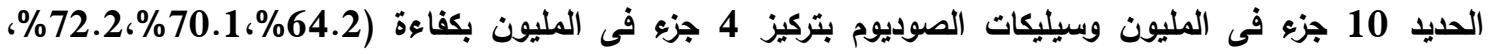
73.2\% و 73.2 \% على الترتيب). ويصفة عامه زاد معدل انخفاض شدة الاصابة معنويا بزيادة التركيز للمعاملات. 
بينما تحت ظروف العدوى الطبيعيه بالحقل موسمى 2020/2018، ادت جميع المعاملات الى حدوث خفض معنوى

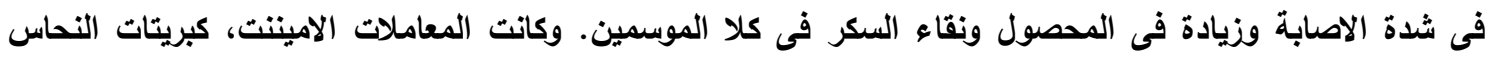

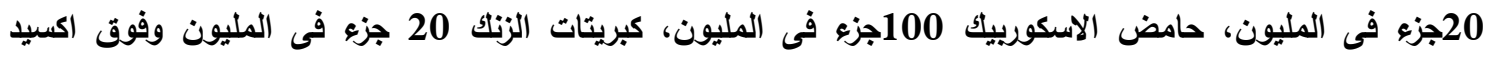

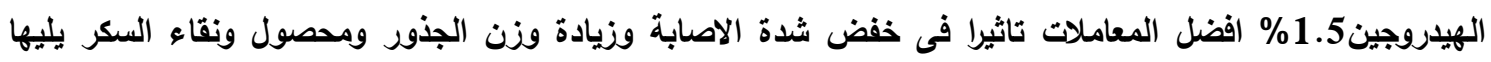

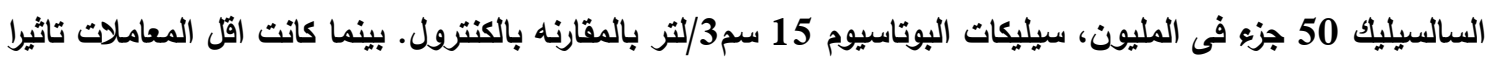
هى كبريتات الماغنيسيوم 30 جزء فى المليون يليها كبريتات الحديد ثم خليط NPK بتوليفة

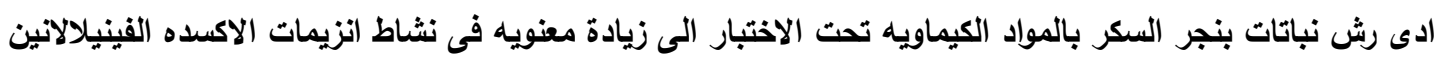

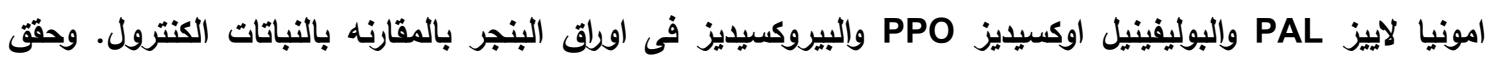

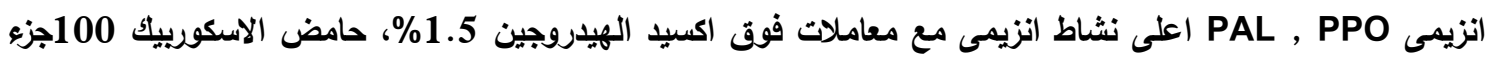

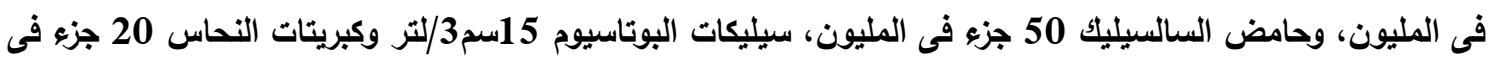

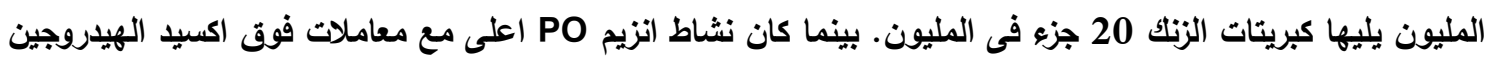

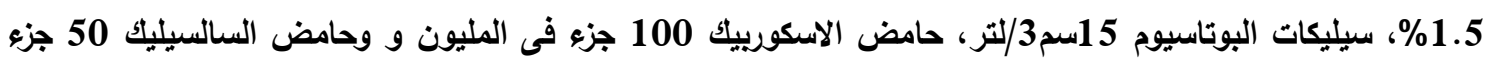

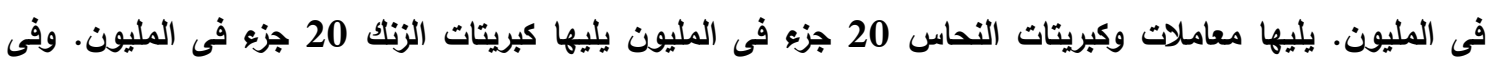
المقابل كانت معاملة N مبيد الامينتت اقل المعاملات تاثيرا على النشاط الانزيمى بالمقارنها بالكتنترول.

أ.د. عصمت المرسـاوى معهل بحوث أمراض النبات ، مركز البحوث الزراعية

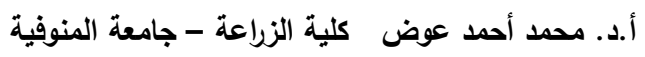

